\title{
Traceable pH and ISE measurements in clinical chemistry (Mesurages traçable de pH et ISE dans la chimie clinique)
}

\author{
Frank Bastkowski ${ }^{1, a}$, Petra Spitzer ${ }^{1}$, Ralf Eberhardt ${ }^{1}$ and Beatrice Adel ${ }^{1}$ \\ ${ }^{1}$ Physikalisch-Technische Bundesanstalt, Bundesallee 100, 38116 Braunschweig, Germany
}

\begin{abstract}
Reliable analysis results are indispensable in clinical chemistry for unambiguous diagnosis. Hence today traceability of the patient measurement to the SI system is established within the scope of a traceability system consisting of a national metrology institute and routine- and reference laboratories.
\end{abstract}

\section{State of the Art of $\mathrm{pH}$ - and ISE measurements in clinical chemistry}

\section{$1.1 \mathrm{pH}$ measurements}

Traceability of $\mathrm{pH}$ measurement results in general is secured by calibration of a $\mathrm{pH}$ measuring device using calibration solutions, which are linked to internationally agreed standards. In clinical chemistry samples usually contain proteins or even blood cells, which can have a disturbing effect at the liquid junction of the used $\mathrm{pH}$ electrode. These effects have to be taken into account with the calculation of the measurement uncertainty.

\subsection{ISE measurements}

Currently in clinical chemistry analytical chemical results for metal ions are reported in terms of substance concentration relative to the substance concentration in primary aqueous calibrators (i.e. mol per litre) as recommended in the IFCC guidelines.[1] However, ion selective electrodes (ISE), which are widely used in clinical chemistry, measure ion activities. The measured activities are transformed into concentrations using empirical factors, which are only valid for "normal" physiological conditions, resulting in false positive or false negative results of the metal ion concentrations in case of special conditions like cancer or renal trauma.

For historical reasons and in order to avoid confusion with the introduction of ion activities, concentration values are still reported in clinical chemistry to date.

The aim of a collaboration project between PTB and representatives from the clinical chemistry section is to bring ISE measurement results for sodium and potassium of blood serum in consent with results from ICP-OES

\footnotetext{
${ }^{\mathrm{a}}$ Corresponding author: frank.bastkowski@ptb.de
}

measurements aiming to establish a reliable link between activities and concentrations of metal ions in blood serum.

\section{Development of a traceable $\mathrm{pH}$ - and ISE reference setup for clinical chemical purposes}

At PTB (Physikalisch-Technische Bundesanstalt) a flowthrough measurement setup was developed, which allows SI-traceable measurements of $\mathrm{pH}$ and metal ion activities at the same time in small volumes.

The use of a miniaturised flow through cell allows $\mathrm{pH}-$ and ISE measurements, which are traced back to the SI system of units by use of primary calibration standards. The use of a special commercial gel-filled $\mathrm{pH}$ glass electrode which is suitable for $\mathrm{pH}$ measurements in protein containing solutions like blood serum together with a precise temperature control $(< \pm 50 \mathrm{mK})$ results in measurement uncertainties of less than $0.02 \mathrm{pH}$ units.

Traceability of the ISE measurement results was established by uncertainty approximation of ion activity coefficients by Pitzer theory.[2] These coefficients are used to calculate ion activities from molalities of the gravimetrically prepared aqueous calibration standards. The novel ISE measuring procedure was validated in an international laboratory comparison.[3]

The combined $\mathrm{pH} / \mathrm{ISE}$ measurement setup will be transferred into practical use together with collaboration partners from the clinical chemistry section.

\section{References}

[1] R. W. Burnett, A. K. Covington, N. Fogh-Andersen, W. R. Külpmann, A. H .J. Maas, O. Müller-Plathe, A. L. Van Kessel, P. D. Wimberley, W. G. Zijlstra, O. Siggard- 
Andersen, H. F. Weisberg, Eur. J. Clin. Chem. Clin.

Biochem. 33, 399-404 (1995).

[2] F. Bastkowski, P. Spitzer, R. Eberhardt, B. Adel, S. Wunderli, D. Berdat, H. Andres, O. Brunschwig, M. Máriássy, R. Fehér, C. Demuth, F. B. Gonzaga, A. Vospělová, M. Vičarová, S. Srithongtim, Pitzer ion activities in mixed electrolytes for possible clinical chemical ISE calibration purposes, manuscript submitted to Accreditation and Quality Assurance.

[3] Euramet (2011) Ion activity measurement of $\mathrm{Na}^{+}, \mathrm{K}^{+}, \mathrm{Ca}^{2+}, \mathrm{Mg}^{2+}$ and $\mathrm{Cl}^{-}$in water based mixed electrolyte samples.

http://www.euramet.org/index.php?id=tc-

projects\&tx nneurametctcp projects[project] $=934 \&$ tx nneurametctcp projects[action] =show\&tx nneur ametctcp projects[controller] $=$ Project $\& \mathrm{cHash}=30 \mathrm{~b} 0$ $\underline{48374708 \mathrm{c} 8 \mathrm{e} 751609 \mathrm{~b} 2460 \mathrm{dc} 9016}$ 